\title{
The effects of laminarin derived from Laminaria digitata on measurements of gut health: selected bacterial populations, intestinal fermentation, mucin gene expression and cytokine gene expression in the pig
}

\author{
A. G. Smith, J. V. O’Doherty, P. Reilly, M. T. Ryan, B. Bahar and T. Sweeney* \\ School of Agriculture, Food Science and Veterinary Medicine, University College, Dublin, Republic of Ireland \\ (Received 19 May 2010 - Revised 6 September 2010 - Accepted 7 September 2010 - First published online 21 January 2011)
}

\section{Abstract}

The aim of the present study was to establish the optimum inclusion level of laminarin derived from Laminaria digitata on selected microbial populations, intestinal fermentation, cytokine and mucin gene expression in the porcine ileum and colon. A total of twentyone pigs (mean body weight $17.9 \mathrm{~kg}$ ) were randomly assigned to one of three dietary treatments: T1 - basal (control) diet, T2 and T3 - basal diets supplemented with laminarin included at 300 and 600 parts per million (ppm), respectively. Selected intestinal bacterial populations and volatile fatty acid (VFA) concentrations were measured in the ileum and colon. Relative gene expression levels for specific cytokine and mucin genes were investigated in ileal and colonic tissue in the absence and presence of a lipopolysaccharide (LPS) challenge. There was an up-regulation of $M U C 2$ gene expression at the $300 \mathrm{ppm}$ inclusion level in the ileum. In the colon, there was a significant reduction in the enterobacteriaceae population at the $300 \mathrm{ppm}$ inclusion level $(P=0.0421)$. Dietary supplementation of $600 \mathrm{ppm}$ laminarin led to a significant increase in MUC2 $(P=0.0365)$ and MUC4 $(P=0.0401)$ expression in the colon, and in the total VFA concentration in the caecum $(P=0.0489)$. A significant increase was also recorded in $I L-6(P=0.0289)$ and $I L-8$ gene expression $(P=0.0245)$ in LPS-challenged colonic tissue at both laminarin inclusion levels. In conclusion, dietary inclusion of $300 \mathrm{ppm}$ laminarin appears to be the optimum dose in the present study due to the reduction in the enterobacteriaceae populations and enhanced IL- 6 and IL- 8 cytokine expression in response to an ex vivo LPS challenge.

Key words: $\beta$-Glucan: Pigs: Colon: Ileum: Microbiota: Immunity: Mucin

While dietary supplementation with in-feed antibiotics promotes growth and feed efficiency in swine, the 2006 European Union widespread prohibition of such antibiotics has prompted the search for alternatives. The use of natural supplements, such as $\beta$-glucans, is currently under consideration as an alternative to in-feed antibiotics ${ }^{(1,2)}$. $\beta$-Glucans are a heterogeneous group of glucose polymers, which form the main constituent of the cell walls of cereals, fungi, macroalgae and a limited number of bacteria ${ }^{(3)}$. The two major types of polysaccharides in seaweeds are structural and storage polysaccharides ${ }^{(4)}$. After carbon, laminarin is the second major storage component in brown algae ${ }^{(5)}$. Laminarin is a seaweed-derived (1-3) $\beta$-D-glucan with a chemical structure consisting mainly of a linear $\beta-(1-3)$ linked glucan with some random $\beta$-(1-6)-linked side chains, which is dependent on the variety of seaweed ${ }^{(6)}$. Water-soluble $\beta$-glucans such as those derived from Laminaria digitata contain small numbers of $\beta-(1-6)$ linked side chains, while water-insoluble $\beta$-glucans such as those derived from $L$. hyperborea only contain linear $\beta$-(13 -linked residues ${ }^{(7)}$. Other sources of $\beta$-glucans extracted from barley and oats are similar in structure but differ in the ratio of $\beta-(1-3): \beta-(1-4)$ linkages $^{(8)}$. $\beta$-Glucans in yeast and macroalgae are polysaccharides characterised by a basic structure of chains of glucose molecules that have a $\beta$-(1-3)-linked backbone with (1-6)-linked branches.

As well as being considered as a source of dietary fibre in monogastric nutrition ${ }^{(9)}, \beta$-glucans also have distinctive immunomodulatory characteristics ${ }^{(10)}$. They bind to mammalian non-Toll-like receptor (TLR) pattern-recognition receptors such as dectin-1, complement receptor 3, lactosylceramide and scavenger receptors, thereby stimulating innate immunity through the activation of macrophages, dendritic cells, neutrophils, natural killer cells and helper T-cells ${ }^{(11)}$. The activation/proliferation of these cells results in enhanced phagocytosis and oxidative burst, cytokine production, activation of the alternative complement pathway and release of lysosomal enzymes ${ }^{(12)}$.

Abbreviations: cDNA, complementary DNA; LPS, lipopolysaccharide; ppm, parts per million; TLR, Toll-like receptor; VFA, volatile fatty acid. 
Recent studies have indicated that the inclusion of laminarin derived from Laminaria spp. in pig diets has ameliorated feed efficiency and growth performance ${ }^{(13-15)}$ and reduced Enterobacterium spp. ${ }^{(15,16)}$. Dietary laminarin inclusion also affects the quality and quantity of mucin production in the jejunum, ileum, caecum and colon in the murine model ${ }^{(17)}$. Mucins are a family of large heterogeneous, complex glycoproteins that are subdivided into two main groups; secreted gel-forming (MUC2, MUC5AC, MUC5B, MUC6 and MUC19) and non-gel-forming (MUC7) and membrane-bound mucins (MUC1, MUC3A/B, MUC4, MUC12, MUC13, MUC15, MUC16, MUC17 and MUC20 $)^{(18,19)}$. Within the gastrointestinal tract, mucins are an integral rheological component of the mucous gel layer, which acts as a biophysical barrier to protect the underlying epithelium from biological, mechanical and chemical insult and pathogenic invasion ${ }^{(19)}$. However, it is clear that $\beta$-glucans vary in their structure and chemical composition, which may modulate their effect on animal performance and gastrointestinal health and hence the optimal dietary inclusion level ${ }^{(1,2,20-22)}$. Therefore, the aim of the present study was to establish the optimum inclusion level of laminarin derived from L. digitata on piglet performance, selected bacterial populations, volatile fatty acid (VFA) production, as well as mucin gene expression and cytokine expression in both unchallenged and lipopolysaccharide (LPS)-challenged ileal and colonic tissues.

\section{Materials and methods}

\section{Experimental design and animal diets}

All procedures described in this experiment were conducted under experimental licence from the Irish Department of Health in accordance with the Cruelty to Animals Act, 1876, and the European Communities (Amendments of the Cruelty to Animals Act, 1876) Regulations ${ }^{(23)}$.

This experiment was designed as a complete randomised design. A total of twenty-one 56-d-old pigs, previously weaned at $26 \mathrm{~d}$ with an initial live weight of 17.9 (sEm 2.2) kg, were blocked on the basis of live weight. Then, seven pigs were randomly assigned to one of the three dietary treatments as follows: T1 - basal diet (control: $n$ 7); T2 - basal diet supplemented with 300 parts per million (ppm) laminarin from L. digitata $(n 7)$; and T3 - basal diet supplemented with $600 \mathrm{ppm}$ laminarin from $L$. digitata $(n 7)$. Experimental feeding continued for $21 \mathrm{~d}$ ad libitium. Purified laminarin ( $990 \mathrm{~g} / \mathrm{kg}$ laminarin) was sourced from Bioatlantis Limited, Tralee, County Kerry, Republic of Ireland, and extracted according to the procedure described by Lynch et al. ${ }^{(16)}$. The molecular weight of laminarin was measured using the method of Friedlaender et al. ${ }^{(24)}$ and was calculated to be less than $5000 \mathrm{Da}$. The diets were formulated to have similar digestible energy $(14.4 \mathrm{MJ} / \mathrm{kg})$ and ileal digestible lysine
$(12.5 \mathrm{~g} / \mathrm{kg})$ contents. The ingredient composition and chemical analysis of the dietary treatments are presented in Table 1.

\section{Animals and management}

Initially, twenty-one pigs were housed individually in fully slated pens $(1.7 \mathrm{~m} \times 1.2 \mathrm{~m})$ and were allowed a $10 \mathrm{~d}$ dietary adaptation period after which time they were weighed and transferred to individual metabolism crates, which facilitated total but separate collection of urine and faeces. The pigs were given a further $5 \mathrm{~d}$ to adapt to the metabolism crates before collections begun. A $5 \mathrm{~d}$ collection period followed to facilitate the nutrient digestibility study. The daily food allowance (digestible energy intake in $\mathrm{MJ} / \mathrm{d}$ ) was calculated as $3.44 \times$ live weight ${ }^{0.54}$ according to Close ${ }^{(25)}$ and was divided over two meals each day. Water was provided with the meals on a 1:1 ratio, and between meals, fresh water was provided ad libitium. The metabolism crates were located in an environmentally controlled room, which was maintained at a constant temperature of $22 \pm 1.5^{\circ} \mathrm{C}$ throughout the experiment. During collections, total faeces weight was recorded daily. At the end of the collection period, faecal samples were pooled and a subsample retained for laboratory analysis. The pigs were then rehoused to their respective pens and diets until they were humanely killed by euthanol injection (pentobarbitone sodium BP) at a rate of $1 \mathrm{ml} / 1.4 \mathrm{~kg}$ body weight.

Table 1. Diet composition and chemical analysis of experimental diets $(\mathrm{g} / \mathrm{kg}$, unless otherwise indicated)

\begin{tabular}{|c|c|c|c|}
\hline $\begin{array}{l}\text { Dietary composition } \\
\text { and analysis }\end{array}$ & $\begin{array}{l}\text { Treatment } 1 \\
\text { (basal diet) }\end{array}$ & $\begin{array}{c}\text { Treatment } 2 \\
\text { (basal diet }+ \\
300 \text { ppm) }\end{array}$ & $\begin{array}{c}\text { Treatment } 3 \\
\text { (basal diet }+ \\
600 \mathrm{ppm} \text { ) }\end{array}$ \\
\hline \multicolumn{4}{|l|}{ Composition (g/kg) } \\
\hline Wheat & 686.7 & $686 \cdot 7$ & $686 \cdot 7$ \\
\hline Soya bean meal & $260 \cdot 0$ & $260 \cdot 0$ & $260 \cdot 0$ \\
\hline Soya oil & $24 \cdot 8$ & 24.8 & 24.8 \\
\hline Minerals and vitamins* & $23 \cdot 0$ & 23.0 & $23 \cdot 0$ \\
\hline Lys $\mathrm{HCl}$ & 3.4 & 3.4 & 3.4 \\
\hline L-Thr & 1.3 & 1.3 & 1.3 \\
\hline DL-Met & 0.8 & 0.8 & 0.8 \\
\hline Laminarin extract (ppm) & 0 & 300 & 600 \\
\hline \multicolumn{4}{|l|}{$\begin{array}{l}\text { Analysed composition } \\
(\mathrm{g} / \mathrm{kg})\end{array}$} \\
\hline DM & 864.7 & $836 \cdot 2$ & 818.6 \\
\hline Crude protein $(n \times 6.25)$ & $189 \cdot 6$ & $208 \cdot 3$ & $206 \cdot 4$ \\
\hline Neutral-detergent fibre & $112 \cdot 6$ & $123 \cdot 2$ & $131 \cdot 1$ \\
\hline Ash & $45 \cdot 50$ & 46.45 & $45 \cdot 34$ \\
\hline \multicolumn{4}{|l|}{ Gross energy $(\mathrm{MJ} / \mathrm{kg})$} \\
\hline $\mathrm{Ca}$ & 6.90 & $6 \cdot 60$ & $6 \cdot 82$ \\
\hline $\mathrm{P}$ & 4.35 & 4.55 & $4 \cdot 17$ \\
\hline Lyst & $10 \cdot 0$ & $10 \cdot 0$ & $10 \cdot 0$ \\
\hline Met and Cys $†$ & $6 \cdot 0$ & $6 \cdot 0$ & $6 \cdot 0$ \\
\hline Thrt & 6.5 & 6.5 & 6.5 \\
\hline Tryt & 1.8 & 1.8 & 1.8 \\
\hline
\end{tabular}

ppm, Parts per million.

*Vitamin and mineral inclusion (per kg diet): $3 \mathrm{mg}$ retinol, $0.05 \mathrm{mg}$ cholecalciferol, $40 \mathrm{mg} \alpha$-tocopherol, $25 \mathrm{mg} \mathrm{Cu}$ as copper (II) sulphate, $100 \mathrm{mg} \mathrm{Fe}$ as iron (II) sulphate, $100 \mathrm{mg} \mathrm{Zn}$ as zinc oxide, $0.3 \mathrm{mg}$ Se as sodium selenite, $25 \mathrm{mg} \mathrm{Mn}$ as manganese oxide and $0.2 \mathrm{mg}$ iodine as calcium iodate on a calcium sulphate/ calcium carbonate carrier.

†Calculated from proximate analysis ${ }^{(52)}$. 


\section{Chemical analysis for nutrient digestibility}

Both concentrates and faeces were analysed for N, DM, ash, gross energy and neutral-detergent fibre. Following collection, faeces were dried at $100^{\circ} \mathrm{C}$ for $48 \mathrm{~h}$. The concentrates and dried faeces samples were milled through a $1 \mathrm{~mm}$ screen (Christy and Norris hammer mill). The DM of faeces and feed was determined after drying overnight at $103^{\circ} \mathrm{C}$. Ash was determined after ignition of a known weight of concentrates or faeces in a muffle furnace (Nabertherm, Bremen, Germany) at $500^{\circ} \mathrm{C}$. The $\mathrm{N}$ content of both feed and faeces was determined using the LECO FP 528 instrument (Leco Instruments, UK Limited, Hazel Grove, Stockport, Cheshire, UK). The neutral-detergent fibre was determined using a Fibertec extraction unit (Tecator, Hoganas, Sweden). The gross energy of the feed and faeces was determined using a Parr 1201 oxygen bomb calorimeter (Parr, Moline, IL, USA). The total laminarin content in the diets was determined using a Megazyme kit (Megazyme, Bray, County Wicklow, Republic of Ireland).

\section{Microbial and volatile fatty acid analysis}

Immediately after slaughter, the entire digestive tract was removed by blunt dissection, and digesta (approximately 10 (SEM 1) g was removed from the ileum, $10 \mathrm{~cm}$ from the ileocaecal valve and from the second loop of the ascending colon. These digesta samples were removed and stored in sterile containers (Sarstedt, County Wexford, Republic of Ireland) on ice and transported to the laboratory immediately. Bifidobacteria, lactobacilli and enterobacteriaceae were isolated according to the methods described by Pierce $e t a l .{ }^{(26)}$. In brief, a $1.0 \mathrm{~g}$ sample was removed from each digesta sample, serially diluted (1:10) in $9.0 \mathrm{ml}$ aliquots of maximum recovery diluent (Oxoid, Basingstoke, UK) and spread plated $(0.1 \mathrm{ml}$ aliquots) onto selective agars as follows: lactobacilli and bifidobacteria were isolated on de Man, Rogosa and Sharpe agar (Oxoid). Lactobacilli were incubated overnight $(18-24 \mathrm{~h})$ at $37^{\circ} \mathrm{C}$ in a microaerophilic $\left(5 \% \mathrm{CO}_{2}\right)$ environment, and the bifidobacteria cultures were incubated anaerobically at $37^{\circ} \mathrm{C}$ for $72 \mathrm{~h}$ according to the manufacturer's instructions (Oxoid). An API 50 CHL kit (BioMerieux, Craponne, France) was used to confirm the presence of lactobacilli, and a Gram stain was used to distinguish bifidobacteria from lactobacilli based on colony appearance and rod size and shape. Enterobacteriaceae were isolated on MacConkey agar (Oxoid), following aerobic incubation at $37^{\circ} \mathrm{C}$ for $18-24 \mathrm{~h}$. Positive enterobacteriaceae colonies were confirmed with API 20E (BioMerieux). Microbial colonies from each plate were counted, and bacterial numbers were presented as $\log _{10}$ colony-forming units/g of digesta. Digesta samples were collected from the ileum, caecum and colon, and were mixed with sodium benzoate and phenylmethylsulphonyl fluoride, in order to stop any bacterial activity and minimise the effects of post-thawing fermentation on resulting VFA concentrations. The VFA analysis was performed using GLC according to the method described by Pierce et al. ${ }^{(26)}$. All $\mathrm{pH}$ measurements were made on a Mettler Toledo MP220 pH meter. Distilled water was added to very viscous digesta samples to allow their $\mathrm{pH}$ to be read.

\section{Collection of tissue samples and tissue challenge procedure}

Ileal and colonic tissues were sampled from the same location as described for microbiological samples. Excised tissues were emptied by dissecting them along the mesentery and rinsing them using sterile phosphate-buffered saline (Oxoid). Tissue sections of $1 \mathrm{~cm}^{3}$, which had been stripped of the overlying smooth muscle, were cut from each tissue. Two sections from each tissue were placed in $1 \mathrm{ml}$ of Dulbecco's modified Eagle's medium (Gibco; Invitrogen Corporation, San Diego, CA, USA), one in the presence of bacterial LPS (Sigma-Aldrich Corporation, St Louis, MO, USA) at a concentration of $10 \mu \mathrm{g} / \mathrm{ml}$. The other tissue sample was used as a control and incubated in sterile Dulbecco's modified Eagle's medium in the absence of LPS. Both challenged and unchallenged tissues were incubated at $37^{\circ} \mathrm{C}$ for $90 \mathrm{~min}$ before being removed, blotted dry and weighed. Approximately, 1000-2000 mg of the porcine ileum and colon tissues were cut into small pieces and stored in $15 \mathrm{ml}$ of RNAlater ${ }^{\circledR}$ (Applied Biosystems, Foster City, CA, USA) overnight at $4{ }^{\circ} \mathrm{C}$. The RNAlater ${ }^{\circledR}$ was then removed before storing the samples at $-80^{\circ} \mathrm{C}$.

\section{RNA extraction and complementary DNA synthesis}

RNA was extracted from approximately $50 \mathrm{mg}$ tissue samples using the GenElute Mammalian Total RNA Miniprep Kit (Sigma Aldrich Corporation) according to the manufacturer's instructions. The purity of the total RNA was analysed using $1 \mu \mathrm{l}$ of total RNA on a NanoDrop spectrophotometer ND1000 (Thermo Scientific, Wilmington, DE, USA), and samples with a 260:280 ratio $\geq 2 \cdot 0$ were considered suitable for complementary DNA (cDNA) synthesis. Total RNA integrity (i.e. quality and quantity) was also assessed by analysing $1 \mu l$ of total RNA using the Agilent 2100 Bioanalyser version A.02.12 (Agilent Technologies, Inc., Santa Clara, CA, USA) using RNA Nano LabChips ${ }^{\circledR}$ (Caliper Technologies Corporation, Mountain View, MA, USA)

The cDNA synthesis was performed using $1 \mu \mathrm{g}$ of total RNA and oligo $(\mathrm{dT})_{20}$ primers in a final reaction volume of $20 \mu \mathrm{l}$ using a Superscript ${ }^{\mathrm{TM}}$ III First-Strand synthesis Kit (Invitrogen Life Technologies, Carlsbad, CA, USA) following the manufacturer's instructions.

\section{Real-time quantitative $P C R$ and normalisation of quantitative $P C R$ data}

All primers for selected cytokines; genes such as interferon $\gamma, I L-1 \alpha, I L-6, I L-8, I L-1 O, I L-17, T N F-\alpha$, the mucin genes 
0
0
0
0
0
0
0
0
0
0
0
4
0
0
0
0
0
0

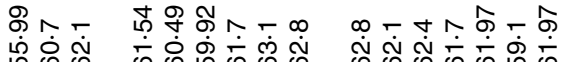

นำ 8 ฮ

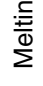
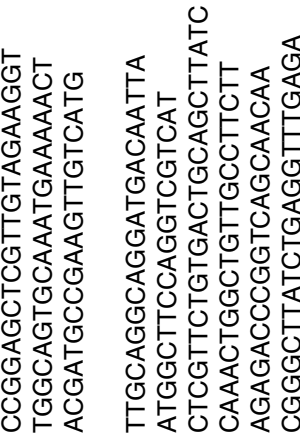

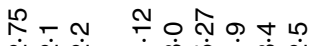

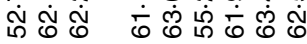

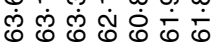
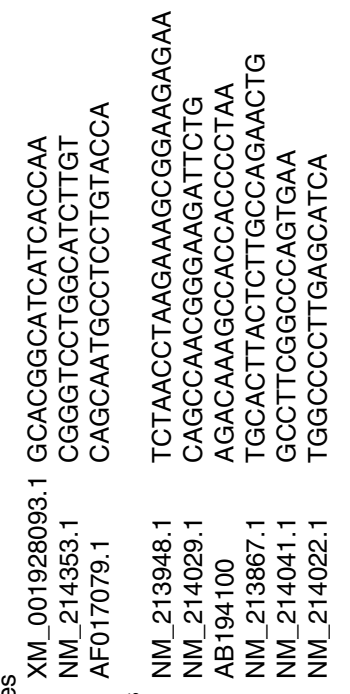

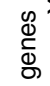

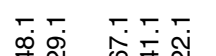

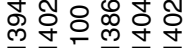

$\bar{N} \bar{N} \bar{\sigma} \bar{\sim} \bar{N} \bar{N}$

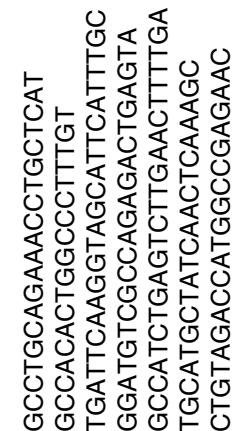

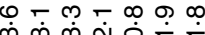
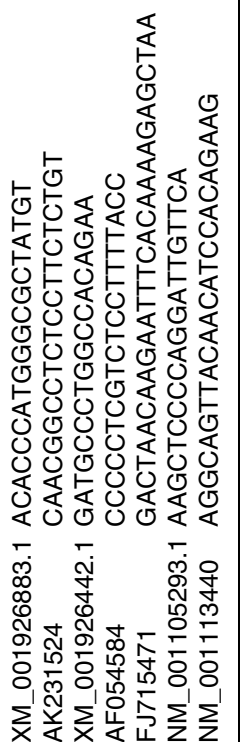

(MUC 1, 2, 4, 5AC, 12, 13 and 20) and three porcine reference genes, $\beta$-actin $(A C T B)$, glyceraldehyde-3-phosphate dehydrogenase and peptidylprolyl isomerase A, were designed using Primer Express ${ }^{\mathrm{TM}}$ (PE Applied Biosystems) and synthesised by MWG Biotech (Milton Keynes, UK). Specificity was established in silico using BLAST and confirmed by examining the dissociation curves for each primer set. The efficiencies of all primer sets were established using a semi-log curve of quantity $v$. $C_{\mathrm{t}}$ of twofold serial dilutions of cDNA (Table 2). Quantitative PCR was then carried out on cDNA using the ABI PRISM 7500 Fast sequence detection system for ninety-six-well plates (Applied Biosystems). All samples were prepared in duplicate using SYBR Green Fast PCR Master Mix (Applied Biosystems), cDNA as the template and specific primers for the genes selected. For each reaction, $5 \mu \mathrm{l}$ cDNA, 1.2 $\mu \mathrm{l}$ forward and reverse primer mix $(5 \mu \mathrm{M})$ and $10 \mu \mathrm{l}$ Fast SYBR Green PCR Master Mix (PE Applied Biosystems) were added and made up to a final volume of $20 \mu \mathrm{l}$. The two-step PCR programme was as follows: $95^{\circ} \mathrm{C}$ for $10 \mathrm{~min}$ for one cycle, followed by $95^{\circ} \mathrm{C}$ for $15 \mathrm{~s}$ and $60^{\circ} \mathrm{C}$ for $1 \mathrm{~min}$ for forty cycles.

The raw $C_{\mathrm{t}}$ values for the reference genes were converted to relative quantities using the formula $Q=E \Delta C_{\mathrm{t}}$, where $E$ is the PCR efficiency of the assay and $\Delta C_{\mathrm{t}}$ is the value calculated for the difference between the lowest $C_{\mathrm{t}}$ value and the $C_{\mathrm{t}}$ value of the sample in question for each gene. The relative quantities of the endogenous controls were then analysed for stability in geNorm ${ }^{(27)}$. The stability ' $M$ ' value generated by the geNorm application for the selected endogenous controls ( $\beta$-actin, glyceraldehyde3 -phosphate dehydrogenase and peptidylprolyl isomerase A), which was less than 1.5 , indicated their suitability as endogenous controls for these intestinal samples. The geometric mean of the relative quantities for $\beta$-actin, glyceraldehyde-3-phosphate dehydrogenase and peptidylprolyl isomerase A (normalisation factor) was then calculated using geNorm. The relative quantities were divided by the normalisation factor (obtained in geNorm) for that sample to give the final normalised relative expression for each target gene. Results for both the unchallenged and challenged experiments are presented in Tables 3 and 4 as the least-square means of fold change of normalised relative gene expression with their standard errors.

\section{Statistical analysis}

All data from the experiment were analysed as a complete randomised design using the General Linear Model procedure of the Statistical Analysis Systems Institute (1985, version 6.11; SAS Institute, Cary, NC, USA) ${ }^{(28)}$. The statistical model used for animal performance and nutrient digestibility, microbiology and cytokine gene expression data analysis included both the linear and quadratic effects of laminarin inclusion levels. Metabolic live weight (live weight ${ }^{0.75}$ ) was included as a covariate in the models. All 
Table 3. Effect of increasing inclusion levels of laminarin extracted from Laminaria digitata on the immune response in unchallenged ileum and colon tissues

(Least-square means of fold change of normalised relative gene expression with their standard errors; $n 7$ animals)

\begin{tabular}{llllllll}
\hline $\begin{array}{l}\text { L. digitata } \\
\text { inclusion }\end{array}$ & & & & & \multicolumn{2}{c}{ Significance $^{*}$} \\
\cline { 5 - 7 } level & 0 ppm & $300 \mathrm{ppm}$ & $600 \mathrm{ppm}$ & SEM & Linear & Quadratic \\
\hline Ileum & & & & & & \\
IFN- $\gamma$ & 1.000 & 1.278 & 0.841 & 0.233 & NS & NS \\
IL-1 $\alpha$ & 1.000 & 1.141 & 0.597 & 0.148 & NS & NS \\
IL-6 & 1.000 & 1.681 & 0.908 & 0.252 & NS & NS \\
IL-8 & 1.000 & 1.003 & 0.475 & 0.245 & NS & NS \\
IL-10 & 1.000 & 1.128 & 0.646 & 0.229 & NS & NS \\
TNF- $\alpha$ & 1.000 & 1.023 & 0.805 & 0.133 & NS & NS \\
Colon & & & & & & \\
IFN- $\gamma$ & 1.000 & 1.217 & 1.148 & 0.286 & NS & NS \\
IL-1 $\alpha$ & 1.000 & 0.716 & 0.851 & 0.144 & NS & NS \\
IL-6 & 1.000 & 1.579 & 1.788 & 0.434 & NS & NS \\
IL-8 & 1.000 & 1.245 & 1.137 & 0.224 & NS & NS \\
IL-10 & 1.000 & 1.029 & 0.843 & 0.285 & NS & NS \\
TNF- $\alpha$ & 1.000 & 1.400 & 1.446 & 0.301 & NS & NS \\
\hline
\end{tabular}

ppm, Parts per million; IFN, interferon.

${ }^{*}$ Probability of significance: NS $(P>0.05)$.

the data were checked initially for outliers and normality using the PROC Univariate procedure of the SAS Institute (version 6.11 ; SAS Institute) ${ }^{(28)}$. The microbial counts were log-transformed before statistical analysis. The leastsquare difference was used to separate means. The data in the tables are presented as least-square interaction means with their standard errors. The probability value, which denotes significance, is $P<0 \cdot 05$.

\section{Results and discussion}

It is imperative that dietary supplementation does not negatively influence either performance traits or gut health. It would also be beneficial if the supplement could exhibit biological properties that may benefit the host in times of pathogen invasion. In the present study, 300 ppm laminarin did not affect performance or nutrient digestibility. It did not affect the selected bacteria in the ileum, but decreased enterobacteriaceae in the colon. Of particular interest in the present study was the fact that $300 \mathrm{ppm}$ laminarin increased $I L-6$ and $I L-8$ cytokine gene expression in colonic tissue following an LPS challenge. This supports the concept of collaborative signalling between TLR and non-TLR pattern-recognition receptors in the intracellular response to laminarin ${ }^{(29)}$.

\section{Animal performance and nutrient digestibility}

There was no effect on animal performance (food intake, daily gain or food conversion ratio) or digestibility coefficients of DM, organic matter, ash, $\mathrm{N}$ or gross energy with increasing dietary inclusion levels of laminarin $(P>0.05$; results not shown). This lack of an effect of laminarin on any of these performance parameters is important, as any natural alternative feed supplement in the porcine diet should not compromise the host in any way. Gardiner et $a{ }^{(20)}$ reported linear decreases in daily gain, as the level of the Ascophyllum nodosum extract increased in healthy grower-finisher pigs. However, this extract also contained phenolic compounds and alginates and led the authors to conclude that unless the process of extraction removed these components, its use as a commercial feed additive would be limited. As a result, the seaweed extract used in the current experiment contained only laminarin.

\section{Microbiology and volatile fatty acids}

As a large number of intestinal bacterial species are unculturable ${ }^{(30)}$, bifidobacteria and lactobacilli were enumerated as a reflection of changes in the population structure of beneficial bacteria. The relevance of measuring enterobacteriaceae populations as an indicator of pathogenic bacteria is debated; however, increased coliform counts were recorded in the intestine of scouring pigs ${ }^{(31)}$ and the density of coliforms in the gastrointestinal tract is used as an indicator of Salmonella and Escherichia coli in pigs ${ }^{(32-34)}$. Hence, coliform reductions due to dietary intervention are, within limits, considered by many to be beneficial $^{(20,32,35)}$

Increasing the level of laminarin from 0 to $600 \mathrm{ppm}$ had no effect on the bifidobacteria, lactobacilli or enterobacteriaceae populations in the ileum ( $P>0.05$; Table 5 ). While there was no effect on bifidobacteria or lactobacilli populations with increasing levels of laminarin in the colon, there was a decrease at $300 \mathrm{ppm}$ (quadratic; $P=0 \cdot 0421$ ) in enterobacteriaceae populations with no further decrease at $600 \mathrm{ppm}$. While the majority of enterobacteriaceae are commensals, the potential to reduce harmful enterobacteriaceae

Table 4. Effect of increasing levels of laminarin extracted from Laminaria digitata on the immune response in the ileum and colon following an ex vivo lipopolysaccharide tissue challenge

(Least-square means of fold change of normalised relative gene expression with their standard errors; $n 7$ animals)

\begin{tabular}{|c|c|c|c|c|c|c|}
\hline \multirow{2}{*}{$\begin{array}{l}\text { L. digitata } \\
\text { inclusion } \\
\text { level }\end{array}$} & \multirow[b]{2}{*}{$0 \mathrm{ppm}$} & \multirow[b]{2}{*}{300 ppm } & \multirow[b]{2}{*}{600 ppm } & \multirow[b]{2}{*}{ SEM } & \multicolumn{2}{|c|}{ Significance* } \\
\hline & & & & & Linear & Quadratic \\
\hline \multicolumn{7}{|l|}{ Ileum } \\
\hline IFN- $\gamma$ & 1.000 & 0.927 & 1.098 & 0.223 & NS & NS \\
\hline$I L-1 \alpha$ & 1.000 & 1.072 & 1.039 & 0.161 & NS & NS \\
\hline IL-6 & 1.000 & 1.352 & 1.143 & 0.266 & NS & NS \\
\hline IL-8 & 1.000 & $1 \cdot 186$ & 0.903 & 0.362 & NS & NS \\
\hline IL-10 & 1.000 & $1 \cdot 198$ & 1.076 & 0.160 & NS & NS \\
\hline$T N F-\alpha$ & 1.000 & 0.819 & 0.921 & 0.108 & NS & NS \\
\hline \multicolumn{7}{|l|}{ Colon } \\
\hline$I F N-\gamma$ & 1.000 & 2.051 & 1.614 & 0.385 & NS & NS \\
\hline$I L-1 \alpha$ & 1.000 & 0.983 & $1 \cdot 242$ & 0.199 & NS & NS \\
\hline IL-6 & 1.000 & 1.846 & 0.830 & 0.272 & 0.0369 & 0.0289 \\
\hline IL-8 & 1.000 & 1.590 & 1.948 & 0.303 & 0.0245 & NS \\
\hline IL-10 & 1.000 & 0.936 & 1.039 & 0.256 & NS & NS \\
\hline$T N F-\alpha$ & 1.000 & 1.557 & 0.938 & 0.250 & NS & NS \\
\hline
\end{tabular}

ppm, Parts per million; IFN, interferon.

*Probability of significance: NS $(P>0.05)$ 
Table 5. Effect of increasing levels of seaweed extract on selected bacterial populations in the ileum, proximal and distal colon $\left(\log _{10}\right.$ colony-forming units/g digesta with their standard errors) and total volatile fatty acids (VFA) in the ileum, caecum and proximal colon of the pig

(Least-square means with their standard errors; $n 7$ animals)

\begin{tabular}{|c|c|c|c|c|c|c|}
\hline \multirow[b]{2}{*}{ Laminarin inclusion level } & \multirow[b]{2}{*}{ Control } & \multirow[b]{2}{*}{300 ppm } & \multirow[b]{2}{*}{600 ppm } & \multirow[b]{2}{*}{ SEM } & \multicolumn{2}{|c|}{ Significance* $^{*}$} \\
\hline & & & & & Linear & Quadratic \\
\hline \multicolumn{7}{|l|}{ Ileum } \\
\hline Bifidobacteria & 4.94 & 5.44 & 5.51 & 0.708 & NS & NS \\
\hline Lactobacilli & $4 \cdot 14$ & $5 \cdot 15$ & 5.40 & 0.565 & NS & NS \\
\hline Enterobacteriaceae & $2 \cdot 24$ & 3.35 & $2 \cdot 86$ & 0.839 & NS & NS \\
\hline \multicolumn{7}{|l|}{ Colon } \\
\hline Bifidobacteria & $7 \cdot 37$ & $7 \cdot 29$ & 7.46 & 0.365 & NS & NS \\
\hline Lactobacilli & 7.89 & $8 \cdot 16$ & $8 \cdot 19$ & 0.221 & NS & NS \\
\hline Enterobacteriaceae & 5.42 & 3.87 & 4.24 & 0.358 & 0.0345 & 0.0421 \\
\hline \multicolumn{7}{|l|}{ Total VFA } \\
\hline Ileum & $10 \cdot 47$ & $14 \cdot 84$ & $14 \cdot 26$ & $2 \cdot 60$ & NS & NS \\
\hline Caecum & 173.5 & $189 \cdot 2$ & 194.4 & $9 \cdot 70$ & 0.0489 & NS \\
\hline Colon & 185.4 & $146 \cdot 4$ & $161 \cdot 8$ & $13 \cdot 79$ & NS & NS \\
\hline
\end{tabular}

ppm, Parts per million.

${ }^{*}$ Probability of significance: NS $(P>0.05)$.

strains without influencing bifidobacteria and lactobacilli numbers is of great significance to the pig industry. The fact that this laminarin source had no effect on bifidobacteria and lactobacilli numbers is supported by the results of Lynch et $a l^{(16)}$ who supplemented the diet with a similar laminarin source. These data are in contrast to previous studies using crude extracts of seaweeds including $L$. digitata, a combination of $L$. digitata and L. byperborea ${ }^{(36)}$, and $A$. nodosum ${ }^{(20)}$ which all resulted in a general anti-microbial effect on all bacterial species examined.

As the amount and composition of the resident microbiota and fermentable substrate affect the quantity and composition of VFA produced in the large intestine ${ }^{(37)}$, VFA and digesta $\mathrm{pH}$ were analysed as a further indicator of gut health. Seaweed-derived polysaccharides are considered to be a source of dietary fibre as they are resistant to hydrolysis by digestive enzymes in the upper gastrointestinal tract ${ }^{(9)}$, which explains the low concentration of VFA in the ileum of laminarin-supplemented pigs. There was a significant increase in total VFA with increasing levels of laminarin in the caecum (linear; $P=0.0489$ ). These results concur with Reilly et $a l .^{(36)}$ who reported that the highest total VFA concentration was in the caecum with $L$. digitata-derived seaweed extracts. There was no significant alteration in digesta $\mathrm{pH}$ recorded from any of the intestinal regions sampled (data not shown).

\section{Mucin gene expression}

Dietary factors such as fibre, protein and anti-nutritional factors are known to directly influence the synthesis and secretion of mucin from goblet cells and the recovery of mucin in digesta ${ }^{(38-40)}$. As mucin composition can be influenced by post-translational events such as bacterial fermentation, the direct impact of laminarin ingestion was examined by looking at the gene expression profile of key mucin genes (Table 6).

All seven mucin gene transcripts were reliably detected in the porcine colon, but only five of the seven gene transcripts were accurately quantifiable in the ileum (MUC1 and $M U C 5 A C$ were undetectable). An increase in MUC2 was observed in the ileum of pigs supplemented with $300 \mathrm{ppm}$ laminarin (quadratic; $P=0.05$ ) but not at the higher dietary inclusion level. Laminarin supplementation had no effect on the remaining detectable mucin genes (MUC4, MUC12, MUC13 and MUC2O) in the ileum. In the colon, dietary supplementation with laminarin at $600 \mathrm{ppm}$ significantly increased MUC2 $(P=0.0365)$ and MUC4 $(P=0 \cdot 0401)$ expression compared with the control and the $300 \mathrm{ppm}$ laminarin-supplemented animals. The fact that the $600 \mathrm{ppm}$ laminarin inclusion level increased the expression of two genes involved with mucin synthesis is of interest.

In human subjects, maintaining a balance in mucin production and excretion in the gut is important. A number of hypotheses are proposed as the exact mechanisms by which laminarin exerts its affects on mucin gene expression are, as yet, unknown. The induced gene upregulation of MUC2 in the ileum and MUC2 and MUC4 in the colon may be attributed to the solubility of laminarin ${ }^{(7)}$ allowing it to exert a direct effect at a cellular level, because laminarin delivered orally can bind directly and be internalised by intestinal epithelial cells and gutassociated lymphoid tissue cells in the murine model ${ }^{(41)}$. In addition to other colonic functions such as water and mineral absorption, indigestible dietary fibres are also broken down in the colon by resident microbiota. Also, since laminarin is regarded as a source of dietary fibre, the increase in $M U C 2$ and MUC4 gene expression may be due to direct stimulation of the colonic mucosa by the increased level of dietary fibre at $600 \mathrm{ppm}$. This 
Table 6. Effect of increasing levels of laminarin extracted from Laminaria digitata on mucin gene expression in the ileum and colon

(Least-square means of fold change of normalised relative gene expression with their standard errors; $n 7$ animals)

\begin{tabular}{|c|c|c|c|c|c|c|}
\hline \multirow{2}{*}{$\begin{array}{l}\text { L. digitata } \\
\text { inclusion level }\end{array}$} & \multirow[b]{2}{*}{$0 \mathrm{ppm}$} & \multirow[b]{2}{*}{300 ppm } & \multirow[b]{2}{*}{600 ppm } & \multirow[b]{2}{*}{ SEM } & \multicolumn{2}{|c|}{ Significance* } \\
\hline & & & & & Linear & Quadratic \\
\hline \multicolumn{7}{|l|}{ Ileum } \\
\hline MUC2 & 1.000 & 1.910 & 0.823 & 0.317 & 0.0421 & 0.0256 \\
\hline MUC4 & 1.000 & $2 \cdot 287$ & 1.697 & 0.637 & NS & NS \\
\hline MUC12 & 1.000 & 1.096 & $2 \cdot 311$ & 0.776 & NS & NS \\
\hline MUC13 & 1.000 & 0.558 & 1.062 & 0.326 & NS & NS \\
\hline MUC20 & 1.000 & $1 \cdot 115$ & 0.870 & 0.227 & NS & NS \\
\hline \multicolumn{7}{|l|}{ Colon } \\
\hline MUC1 & 1.000 & 0.902 & 1.270 & 0.098 & NS & NS \\
\hline MUC2 & 1.000 & 0.726 & $1 \cdot 207$ & 0.145 & 0.0461 & 0.0365 \\
\hline MUC4 & 1.000 & 0.981 & 1.351 & 0.097 & 0.0482 & 0.0401 \\
\hline$M U C 5 A C$ & 1.000 & $2 \cdot 134$ & 0.285 & 0.349 & NS & NS \\
\hline MUC12 & 1.000 & 0.957 & $1 \cdot 120$ & 0.193 & NS & NS \\
\hline MUC13 & 1.000 & 0.924 & 1.077 & 0.272 & NS & NS \\
\hline MUC2O & 1.000 & $1 \cdot 107$ & 1.063 & 0.122 & NS & NS \\
\hline
\end{tabular}

up-regulation is consistent with the protective role of mucins in the formation of a 'gut barrier' after mucosal stimulation by dietary fibres ${ }^{(42)}$. Additionally, alteration in intestinal microbiota may also influence mucin synthesis and secretion, as adherence of beneficial bacteria to mucosal epithelia stimulates up-regulation of colonic $M U C 2$ expression in vivo ${ }^{(43)}$ and in vitro $^{(44)}$. Therefore, laminarin supplementation may have increased MUC2 and MUC4 expression indirectly by acting as a substrate for the resident microbiota, which, in turn, up-regulated mucin production.

The increase in mucin gene expression in the present study was interpreted as being beneficial for these animals. Other dietary inclusion studies with different varieties of brown seaweeds (such as A. nodosum) have been shown to increase digesta viscosity, leading to decreased diffusion and efficacy of digestive enzymes, thus leading to an overall decrease in average daily gain in pigs ${ }^{(20)}$. As there was no reduction in average daily gain and all animals remained healthy throughout the course of the study, we propose that increased mucin gene expression may serve to ameliorate mucin turnover, thus maintaining and enhancing the protective mucosal layer in the gastrointestinal tract of these animals. However, further studies measuring mucosal viscosity and/or thickness are required to substantiate this theory.

\section{Cytokine gene expression}

There were no effects of the laminarin inclusion level in unchallenged ileum or colon tissue for any of the cytokines analysed (Table 3). This overall lack of an effect on these inflammatory markers, similar to the lack of effect on animal performance, implies that the presence of laminarin in the diet did not elicit any deleterious effects on either of these two parameters.
To mimic the response of the ileal and colonic tissues of animals exposed to laminarin to a microbial challenge, these tissues were subsequently incubated with LPS ex vivo. While no effect was observed in the ileum (Table 3), a significant challenge effect was observed for $I L-6$ and $I L-8$ gene expression in the colon of LPSchallenged tissue (Table 4). Dietary laminarin inclusion led to an increase in $I L-6$ expression (quadratic; $P=0.0289$ ), while a linear increase in $I L-8$ gene expression was observed $(P=0.0245)$. These data suggest that inclusion of laminarin in the diet could enhance the proinflammatory response to a microbial challenge. The potential benefit of this enhanced gene up-regulation of IL- 6 and IL- 8 cytokines following the LPS challenge is significant for the host, as IL-6 is a pro-inflammatory cytokine that plays an important role in acute inflammation in the early immune response ${ }^{(45)}$. Similarly, chemokine IL-8 also plays an important role in acute inflammation and is responsible for neutrophil recruitment and activation to the initial site of infection ${ }^{(46)}$.

While dietary exposure to laminarin did not stimulate pro-inflammatory cytokine production in the gastric mucosa, it enhanced the LPS-induced pro-inflammatory cytokine production in colonic tissue. These data are of biological interest as they support the concept of collaborative signalling between TLR and non-TLR patternrecognition receptors in immune stimulation ${ }^{(29)}$. LPS induces pro-inflammatory cytokine production via TLR4, while laminarins bind to non-TLR pattern-recognition receptors such as dectin-1, complement receptor 3, lactosylceramide and scavenger receptors ${ }^{(47)}$. The dectin-1 receptor pathway can collaborate via the Syk kinase pathway with a number of MyD88-coupled TLR, including TLR4, to enhance the production of pro-inflammatory cytokines in response to pathogen recognition ${ }^{(48)}$. Hence, the activation of the dectin-1 pathway by laminarin, coupled 
with the activation of TLR 4 by LPS, would explain the enhanced IL-6/IL-8 response. Notwithstanding the fact that the dectin-1 laminarin receptor has recently been identified and characterised in this model ${ }^{(49)}$, Kikkert et $a{ }^{(50)}$ found that small $\beta$-glucan molecules, such as laminarin, while having co-stimulatory effects, were not acting through the dectin-1 pathway, and CR3 has been identified as the major receptor for $\beta$-glucan molecules on human neutrophils ${ }^{(51)}$.

\section{Conclusions}

Laminarin extracted from the brown seaweed, L. digitata, at both dietary inclusion levels of 300 and $600 \mathrm{ppm}$, exerted no deleterious effects on animal performance or immune function in the unchallenged subjects, as all animals remained healthy throughout the course of the present study. Both inclusion levels also increased mucin gene expression and enhanced IL-6 and IL-8 cytokine expression in response to an ex vivo LPS challenge. However, the dietary inclusion of $300 \mathrm{ppm}$ laminarin had the added benefit of reducing potential pathogenic enterobacteriaceae populations in the colon. Therefore, we conclude that $300 \mathrm{ppm}$ was more beneficial than the $600 \mathrm{ppm}$ inclusion level for the animals in the present study. Future studies using several laminarin concentrations will assess the potential of laminarin dietary supplementation to suppress a deliberate in vivo pathogen challenge.

\section{Acknowledgements}

Funding for the present research was provided under the National Development Plan, through the FIRM Fund, administered by the Department of Agriculture, Fisheries and Food, Republic of Ireland. A. G. S. wrote the manuscript, collected the samples and carried out real-time PCR with M. T. R. J. V. O'. D designed the study, analysed the data and participated in writing and correcting the manuscript. P. R. fed the pigs and collected the samples. B. B. extracted RNA the for real-time experiment. T. S. designed the study and participated in writing and correcting the manuscript. None of the authors had any conflict of interest.

\section{References}

1. Hahn TW, Lohakare JD, Lee SL, et al. (2006) Effects of supplementation of $\beta$-glucans on growth performance, nutrient digestibility, and immunity in weanling pigs. J Anim Sci $\mathbf{8 4}$, $1422-1428$.

2. Li J, Li DF, Xing JJ, et al. (2006) Effects of $\beta$-glucan extracted from Saccharomyces cerevisiae on growth performance, and immunological and somatotropic responses of pigs challenged with Escherichia coli lipopolysaccharide. J Anim Sci 84, 2374-2381.

3. Williams DL (1997) Overview of (133)-D-glucan immunobiology. Mediat Inflamm 6, 247-250.

4. MacArtain P, Gill CIR, Brooks M, et al. (2007) Nutritional value of edible seaweeds. Nutr Rev 65, 535-543.
5. Davis TA, Volesky B, Mucci A, et al. (2003) A review of the biochemistry of heavy metal biosorption by brown algae. Water Res 37, 4311-4330.

6. Brown GD \& Gordon S (2005) Immune recognition of fungal $\beta$-glucans. Cell Microbiol 7, 471-479.

7. Read SM, Currie G \& Bacic A (1996) Analysis of the structural heterogeneity of laminarian by electrospray-ionisation-mass spectrometry. Carbohydr Res 281, 187-201.

8. Wood PJ \& Beer MU (1998) Functional oat products. In Functional Foods: Biochemical and Processing Aspects, pp. 1-37 [G Mazza, J Shi and M Le Mayuer, editors]. Lancaster, PA: Technomic Publishing Co.

9. Deville C, Damas J, Forget P, et al. (2004) Laminarin in the dietary fibre concept. J Sci Food Agric 84, 1030-1038.

10. Soltanian S, Stuyven E, Cox E, et al. (2009) Beta-glucans as immunostimulant in vertebrates and invertebrates. Crit Rev Microbiol 35, 109-138.

11. Goodridge HS, Wolf AJ \& Underhill DM (2009) $\beta$-Glucan recognition by the innate immune system. Immunol Rev 230, 38-50.

12. Tsoni SV \& Brown GD (2008) $\beta$-Glucans and dectin-1. Ann N Y Acad Sci 1143, 45-60.

13. Gahan DA, Lynch MB, Callan JJ, et al. (2008) Performance of weanling piglets offered low, medium, or high-lactose diets supplemented with a seaweed extract from Laminaria spp. Animal 3, 24-31.

14. O'Doherty JV, Dillon S, Figat S, et al. (2010) The effects of lactose inclusion and seaweed extract derived from Laminaria spp. on performance, digestibility of diet components and microbial populations in newly weaned pigs. Anim Feed Sci Tech 157, 173-180.

15. McDonnell P, Figat S \& O'Doherty JV (2009) The effect of dietary laminarin and fucoidan in the diet of the weanling piglet on performance, selected faecal microbial populations and volatile fatty acid concentrations. Animal 4, $579-585$.

16. Lynch MB, Sweeney T, Callan JJ, et al. (2010) The effect of dietary Laminaria-derived laminarin and fucoidan on nutrient digestibility, nitrogen utilisation, intestinal microflora and volatile fatty acid concentration in pigs. J Sci Food Agric 90, 430-437.

17. Deville C, Gharbi M, Dandrifosse G, et al. (2007) Study on the effects of laminarin, a polysaccharide from seaweed, on gut characteristics. J Sci Food Agric 87, 1717-1725.

18. Hollingsworth MA \& Swanson BJ (2004) Mucins in cancer: protection and control of the cell surface. Nat Rev Cancer 4, 45-60.

19. Linden SK, Sutton P, Karlsson NG, et al. (2008) Mucins in the mucosal barrier to infection. Mucosal Immunol 1, 183-197.

20. Gardiner GE, Campbell AJ, O'Doherty JV, et al. (2008) Effect of Ascophyllum nodosum extract on growth performance, digestibility, carcass characteristics and selected intestinal microflora populations of grower-finisher pigs. Anim Feed Sci Tech 141, 259-273.

21. Dritz SS, Shi J, Kielian TL, et al. (1995) Influence of dietary beta-glucan on growth performance, nonspecific immunity, and resistance to Streptococcus suis infection in weanling pigs. J Anim Sci 73, 3341-3350.

22. Reilly P, Sweeney T, Pierce KM, et al. (2010) The effect of cereal-derived $\beta$-glucans and enzyme supplementation on the intestinal microbiota, nutrient digestibility, mineral metabolism and volatile fatty acid concentrations in finisher pigs. Anim Feed Sci Tech 156, 165-176.

23. European Communities Regulations (2002) S.I. No. 566 of 2002. Amendment of Cruelty to Animals Act, 1876, Dublin, Ireland. 
24. Friedlaender MHG, Cook WH \& Martin WG (1954) Molecular weight and hydrodynamic properties of laminarin. Biochim Biophys Acta 14, 136-144.

25. Close WH (1994) Feeding new genotypes: establishing amino acid/energy requirements. In Principles of Pig Science, pp. 123-140 [DJA Cole, J Wiseman and MA Varley, editors]. Nottingham: Nottingham University Press.

26. Pierce KM, Sweeney T, Brophy PO, et al. (2005) Dietary manipulation post weaning to improve piglet performance and gastro-intestinal health. Anim Sci 81, 347-356.

27. Vandesompele J, De Preter K, Pattyn F, et al. (2002) Accurate normalization of real-time quantitative RT-PCR data by geometric averaging of multiple internal control genes. Genome Biol 3, research0034.0031-research0034.0011.

28. Statistical Analysis Systems statistical software package version 6.12 (1985) (SAS Institute, Cary, NC, USA).

29. Trinchieri G \& Sher A (2007) Cooperation of Toll-like receptor signals in innate immune defence. Nat Rev Immunol 7 , $179-190$.

30. Leser TD, Amenuvor JZ, Jensen TK, et al. (2002) Cultureindependent analysis of gut bacteria: the pig gastrointestinal tract microbiota revisited. Appl Environ Microbiol $\mathbf{6 8}$, 673-690.

31. Muralidhara KS, Sheggeby GG, Elliker PR, et al. (1977) Effect of feeding lactobacilli on the coliform and Lactobacillus flora of intestinal tissue and feces from piglets. J Food Prot $\mathbf{4 0}$, $288-295$.

32. Mikkelsen LL, Naughton PJ, Hedemann MS, et al. (2004) Effects of physical properties of feed on microbial ecology and survival of Salmonella enterica serovar Typhimurium in the pig gastrointestinal tract. Appl Environ Microbiol 70, 3485-3492.

33. Jørgensen L, Dahl J, Jensen BB, et al. (1999) Effects of Expanding, Pelleting, and Grinding on Salmonella typhimurium Infection, Growth Performance and Gastrointestinal Ecosystem in Slaughter Pigs. Publication no. 426. Copenhagen: The National Committee for Pig Breeding Health and Production.

34. Hojberg O, Canibe N, Knudsen B, et al. (2003) Potential rates of fermentation in digesta from the gastrointestinal tract of pigs: effect of feeding fermented liquid feed. Appl Environ Microbiol 69, 408-418.

35. Demeckova V, Tsourgiannis CA \& Brooks PH (2003) Beneficial changes of lactobacilli, coliforms and E. coli numbers in the feces of farrowing primiparous sows, achieved by fermented liquid feed, positively affect subsequent neonatal colonization. In Proceedings of the 9th International Symposium on Digestive Physiology in Pigs, vol. 2, pp. 78-80 [R Ball, editor]. Edmonton, AB: University of Alberta.

36. Reilly P, O'Doherty JV, Pierce KM, et al. (2008) The effects of seaweed extract inclusion on gut morphology, selected intestinal microbiota, nutrient digestibility, volatile fatty acid concentrations and the immune status of the weaned pig. Animal 2, 1465-1473.
37. Macfarlane S \& Macfarlane GT (2003) Regulation of shortchain fatty acid production. Proc Nutr Soc 62, 67-72.

38. Thomsen LE, Knudsen KEB, Hedemann MS, et al. (2006) The effect of dietary carbohydrates and Trichuris suis infection on pig large intestine tissue structure, epithelial cell proliferation and mucin characteristics. Vet Parasitol 142, $112-122$.

39. Montagne L, Piel C \& Lalles JP (2004) Effect of diet on mucin kinetics and composition: nutrition and health implications. Nutr Rev 62, 105-114.

40. Brownlee IA, Havler ME, Dettmar PW, et al. (2003) Colonic mucus: secretion and turnover in relation to dietary fibre intake. Proc Nutr Soc 62, 245-249.

41. Rice PJ, Adams EL, Ozment-Skelton T, et al. (2005) Oral delivery and gastrointestinal absorption of soluble glucans stimulate increased resistance to infectious challenge. J Pharmacol Exp Ther 314, 1079-1086.

42. Enns ML, Schmidt-Wittig U, Höner K, et al. (1994) Mechanical challenge causes alterations of rat colonic mocusa and released mucins. Alterations of mucosa and mucins. $J$ Exp Anim Sci 36, 128-140.

43. Caballero-Franco C, Keller K, De Simone C, et al. (2007) The VSL\# 3 probiotic formula induces mucin gene expression and secretion in colonic epithelial cells. Am J Physiol Gastrointest Liver Physiol 292, G315-G322.

44. Mattar A, Teitelbaum DH, Drongowski R, et al. (2002) Probiotics up-regulate MUC-2 mucin gene expression in a Caco-2 cell-culture model. Pediatr Surg Int 18, 586-590.

45. Barton B (1996) The biological effects of interleukin 6. Med Res Rev 16, 87-109.

46. Harada A, Sekido N, Akahoshi T, et al. (1994) Essential involvement of interleukin-8 (IL-8) in acute inflammation. $J$ Leukoc Biol 56, 559-564.

47. Brown GD (2006) Dectin-1: a signalling non-TLR patternrecognition receptor. Nat Rev Immunol 6, 33-43.

48. Dennehy KM, Ferwerda G, Faro-Trindade I, et al. (2008) Syk kinase is required for collaborative cytokine production induced through Dectin-1 and Toll-like receptors. Eur $J$ Immunol 38, 500-506.

49. Sonck E, Stuyven E, Goddeeris B, et al. (2009) Identification of the porcine C-type lectin Dectin-1. Vet Immunol Immunopatbol 130, 131-134.

50. Kikkert R, Bulder I, de Groot ER, et al. (2007) Potentiation of Toll-like receptor-induced cytokine production by (1-3)- $\beta$-Dglucans: implications for the monocyte activation test. $J$ Endotoxin Res 13, 140-149.

51. van Bruggen R, Drewniak A, Jansen M, et al. (2009) Complement receptor 3, not Dectin-1, is the major receptor on human neutrophils for $\beta$-glucan-bearing particles. $\mathrm{Mol}$ Immunol 47, 575-581.

52. Sauvant D, Perez JM \& Tran G (2004) Tables of Composition and Nutritional Value of Feed Materials Pigs, Poultry, Cattle, Sheep, Goats, Rabbits, Horses, Fish. Wageningen: Wageningen Academic Publishers. 